\title{
Cultivating Humanity in Legal Education
}

\author{
Martha C. Nussbaum $\dagger$
}

The peoples of the earth have thus entered in varying degrees into a universal community, and it has developed to the point where a violation of laws in one part of the world is felt everywhere.

Immanuel Kant, Perpetual Peace, 1795.'

Global integration is shrinking time, shrinking space and eroding national borders. People's lives are more interdependent. The state's autonomy is declining as new global rules of trade bind national policies and as new global actors wield greater influence.

\section{United Nations Development Programme, Human Development Report 2000.}

Soon we shall breathe our last. Meanwhile, while we live, while we are among human beings, let us cultivate our humanity.

$$
\text { Seneca, On Anger (approximately } 45 \text { A.D.). }{ }^{3}
$$

\section{LEGAL EDUCATION IN AN INTERLOCKING WORLD}

How well do our law schools prepare students for citizenship in an increasingly interlocking and interdependent world? Legal education in the United States, as in most nations of the world, focuses on the study of one nation's legal traditions and ways of reasoning. In this

$\dagger$ Ernst Freund Distinguished Service Professor of Law and Ethics, The University of Chicago, appointed in the Law School, Philosophy Department, and Divinity School; Associate in the Classics Department, Affiliate of the Committee on Southern Asian Studies, member of the Board of the Human Rights Program, Coordinator of the Center for Comparative Constitutionalism. I am grateful to Eric Posner, Richard Posner, and Cass Sunstein for helpful comments on a previous draft, and to José Alvarez, Jeffrey Lehman, Anne-Marie Slaughter, and Mark Tushnet for helpful advice and information.

1 Hans Reiss, ed, Kant: Political Writings 107-08 (Cambridge 2d ed 1991) (H.B. Nisbet, trans). I alter Nisbet's translation of "Recht" from "right" to "law". Here as elsewhere, Kant uses "Recht" to translate Latin ius, frequently including the Latin in parentheses after the German. Often he alludes to classical ideas of natural law, ius naturae. Kant's continuity with Cicero, Seneca, and other Roman authors can best be appreciated if we bear these facts in mind.

2 United Nations Development Programme, Human Development Report 20009 (Oxford 2000).

3 All translations from Seneca's Latin are my own. The best edition of the Latin text of $D e$ Ira (On Anger) is in Seneca, Dialogorum Libri Duodecim 39-128 (Oxford 1977) (L.D. Reynolds, ed). An English-language version may be found at Seneca, On Anger, in Seneca, Moral and Political Essays 17,116 (Cambridge 1995) (John M. Cooper and J.F. Procopé, eds). 
Essay, I examine trends in legal education that confront new configurations of influence and deliberation in today's world. My assessment will be mixed: In some areas pertinent to good global citizenship, the legal academy is making good progress; in others, it has not progressed nearly far enough.

Because I have developed elsewhere a theory of education for global citizenship based on a study of undergraduate liberal arts education in the United States, ${ }^{4}$ I begin with an account of the normative principles I defended in that work, and their rationale. I then ask how far legal education should and could follow similar principles, given its very different purpose. After giving some examples of what might be done to implement a suitably revised version of those principles in legal education, I assess some developments in U.S. law schools with those principles in view.

\section{ANCIENT PHILOSOPHY AND CONTEMPORARY COOPERATION}

The theory of education developed in Cultivating Humanity ${ }^{5}$ has two very different sources: study of the ancient Greek and Roman Stoics, and experience working with an international agency on issues of poverty in developing countries. For the Greek and Roman Stoics, all human beings are fundamentally members of one world order, no matter in what nation they dwell. This view is often referred to as "cosmopolitanism," from the fact that they say that each of us is a "citizen of the world" (in Greek, kosmou politês). ${ }^{6}$ For thinkers such as Cicero,' Seneca, and Marcus Aurelius, the fact that we share a common humanity with people in distant parts of the world means that we have moral obligations to them that transcend the reach of current positive

4 Martha C. Nussbaum, Cultivating Humanity: A Classical Defense of Reform in Liberal Education 50-84 (Harvard 1997) (arguing for a conception of liberal education that will prepare students for global citizenship).

5 See id.

6 See, for example, Martha C. Nussbaum, For Love of Country? (Beacon 2002) (discussing the negative effects of excessive patriotic pride on cosmopolitanism and its ideals); Martha $C$. Nussbaum, Duties of Justice, Duties of Material Aid: Cicero's Problematic Legacy, 8 J Polit Phil 170, 185 (1999) (describing Cicero's conception of the duties of justice as "fully cosmopolitan"); Martha C. Nussbaum, Kant and Stoic Cosmopolitanism, 5 J Polit Phil 1, 4-12 (1997). My book in progress, The Cosmopolitan Tradition, is under contract with Yale University Press (unpublished manuscript on file with author).

For an overall account of Greek and Roman Stoicism, see Martha C. Nussbaum, The Therapy of Desire: Theory and Practice in Hellenistic Ethics (Princeton 1994). See also Malcolm Schofield, The Stoic Idea of the City (Chicago 2d ed 1999) (discussing Stoic political thought).

7 Cicero is not a Stoic, and he has many objections to their ideas in some areas; in his political thought, however, he is quite close to orthodox Stoicism, and De Officiis (On Duties) is one of our fullest accounts of Stoic cosmopolitan ideas. For an English-language version of this account, see Cicero, On Duties (Cambridge 1991) (M.T. Griffin and E.M. Atkins, eds). 
law. These thinkers' ideas became the basis for later development of international law, especially in the area of war and peace. ${ }^{8}$

Since the Stoics believed that people should cooperate across national borders, they had some radical ideas about education. Seneca, a Roman philosopher born in Spain and a regent of the Roman Empire during Nero's youth, was well placed to reflect on these issues, since he lived in a Rome already heterogeneous in ethnic makeup and complexly connected to many different parts of the world. Seneca's Moral Epistle 88, often called "letter on liberal education," is the founding text for our modern idea of liberal education.'

Seneca begins his letter by describing the traditional style of education, noting that it is called "liberal" (liberalis, "connected to freedom"), because it is understood to be an education for well-broughtup young gentlemen, who were called the liberales, the "free-born." He then announces that he will use the term "liberal" in a very different way. In his view, an education is truly "liberal" only if it is one that "liberates" the student's mind, encouraging him or her to take charge of his or her own thinking, leading the Socratic-examined life, and becoming a reflective critic of traditional practices. ${ }^{10}$ Seneca goes on to argue that only this sort of education will develop each person's capacity to be fully human, by which he means self-aware, selfgoverning, and capable of recognizing and respecting the humanity of all our fellow human beings, no matter where they are born, no matter what social class they inhabit, no matter what their gender or ethnic origin. "Soon we shall breathe our last," he concludes in his related treatise On Anger. "Meanwhile, while we live, while we are among human beings, let us cultivate our humanity."

These ideas, I believe, can help us see what is well and not well done in contemporary reforms of liberal education. Liberal education in the United States used to be like the old type of education Seneca describes, an education designed for well-brought-up young gentle-

8 See Nussbaum, $8 \mathrm{~J}$ Polit Phil at 185 (cited in note 6) (outlining "the material in Cicero that became the foundation of modern international law"). A more detailed discussion is in the Grotius chapter of Nussbaum, The Cosmopolitan Tradition (cited in note 6).

9 The best Latin edition is Seneca, Ad Lucilium Epistulae Morales 312-23 (Oxford 1965) (L.D. Reynolds, ed). A complete but unsatisfactory English translation is available in Seneca, $A d$ Lucilium Epistulae Morales (G.P. Putnam's Sons 1917) (Richard M. Gummere, trans). The epistles were probably published around 64-65 A.D. Thus they are quite a bit later than On Anger, but quite consistent in thought.

10 I use "him or her" not just out of contemporary political correctness: Stoic philosophers of the first century A.D. wrote at length about the equal education of women, and defended the view that women as much as men should lead the examined life. See Martha C. Nussbaum, The Incomplete Feminism of Musonius Rufus, Platonist, Stoic and Roman, in Martha C. Nussbaum and Juha Sihvola, eds, The Sleep of Reason: Erotic Experience and Sexual Ethics in Ancient Greece and Rome 283, 286-98 (Chicago 2002).

11 Seneca, On Anger at 117 (cited in note 3). 
men, to acculturate them into the traditional norms and values of the community. During the past twenty years or so, the idea of preparing many different kinds of students for citizenship in a complex world has been gradually taking hold. But there are many conflicting views of how this idea should be realized in practice, and many bitter controversies about new forms of study such as women's studies, the study of human sexuality, the study of non-Western cultures, and the study of race and ethnicity. It is important to develop some general principles to guide the assessment of new curricular initiatives, inspired by what was good in Stoic philosophical ideas and by the best in current educational practice. ${ }^{12}$

The second source of Cultivating Humanity was my experience working at the World Institute for Development Economics Research, an international agency connected with the United Nations University, and located in Helsinki, Finland. Between 1986 and 1993 I worked as a Research Advisor at that Institute, working with Amartya Sen on an interdisciplinary philosophy-economics project that involved developing new ways of thinking about what it is to measure "the quality of life" in a nation. ${ }^{13}$ We challenged the entrenched conception of quality of life as GNP per capita, in favor of a richer, more humanistic, multifaceted approach to development in terms of the goal of promoting "human capabilities," the opportunities or abilities of human beings to do, and to be, certain valuable things. ${ }^{14}$ This approach, at least my part of it, has deep roots in ancient Greek and Roman philosophy, both Aristotelian and Stoic.

While working at the Institute with people from all over the world, I learned a lot about the limits of my own undergraduate (and graduate) education. I saw that while in some respects my education prepared me well for a cross-cultural dialogue, in other respects my preparation was extremely poor. Thinking about how issues of all kinds, ranging from business and industry to the global environment, increasingly bring people together from different cultures for discussions about fundamental norms and principles, I had another vantage

12 Nussbaum, Cultivating Humanity (cited in note 4) focuses on a group of fifteen highly diverse colleges and universities, studying their curricula in especially close detail.

13 These efforts are related to the movement that created the Human Development Reports of the United Nations Development Programme.

14 For this approach, see Martha C. Nussbaum and Amartya Sen, eds, The Quality of Life 1-6 (Clarendon 1993) (suggesting the need to consider capabilities when analyzing prosperity and well-being). My own approach, slightly different from Sen's, is most fully developed in Martha C. Nussbaum, Women and Human Development 11-15 (Cambridge 2000) (developing an account of capabilities as a basis for fundamental social and political entitlements). See also Martha C. Nussbaum, Capabilities as Fundamental Entitlements: Sen and Social Justice, forthcoming in Feminist Economics. 
point for thinking about what a truly "cosmopolitan" education might be.

\section{Cultivating Humanity:The Three CORE VAlues}

Focusing on the required "liberal arts" component of undergraduate education, I argue that three capacities, above all, are crucial to prepare students well for the interlocking world in which they live. Developing these capacities should be the focus of the liberal arts part of the curriculum.

\section{A. Socratic Self-Examination}

First is the capacity for critical examination of oneself and one's traditions - for living what, following Socrates, we may call "the examined life." This means a life that accepts no belief as authoritative simply because it has been handed down by tradition or become familiar through habit, a life that questions all beliefs and accepts only those that survive reason's demand for consistency and justification. Developing this capacity requires training oneself to reason logically, and to test what one reads or says for consistency of reasoning, correctness of fact, and accuracy of judgment.

Testing of this sort frequently produces challenges to tradition, as Socrates knew well when he defended himself against the charge of "corrupting the young." But he defended his activity on the grounds that democracy needs citizens who can think for themselves rather than simply deferring to authority, who can reason together about their choices rather than just trading claims and counterclaims. Like a gadfly on the back of a noble but sluggish horse, he said, he was waking democracy up so that it could conduct its business in a more reflective and reasonable way. This norm of deliberative democracy has not been fully realized in our modern democracies any more than it was in ancient Athens. All too often, mere rhetoric and the attempt to sway public opinion dominate over attempts to reason clearly and well.

To create a truly deliberative and self-aware democracy, we need to give students practice in analyzing and constructing arguments in a Socratic fashion, as well as in showing respect for one another's arguments. Furthermore, following Socrates, students need to think reflectively about the values of their society, learning to defend values that are sound and to criticize those that do not stand the test of deliberation. 


\section{B. World Citizenship}

Citizens who cultivate their humanity need, second, an ability to see themselves as not simply citizens of some local region or group but also, and above all, as human beings bound to all other human beings by ties of recognition and concern. As Seneca and the ancient Stoics knew, we very easily think of ourselves in narrow group terms as Americans first and foremost, as human beings second-or, even more narrowly, as Italian-Americans, or heterosexuals, or AfricanAmericans first, Americans second, and human beings third, if at all. We neglect needs and capacities that link us to fellow citizens who live at a distance, or who look different from ourselves. This means that we are unaware of many prospects of communication and fellowship with them, and also of responsibilities we may have to them. Cultivating our humanity in a complex interlocking world involves understanding the ways in which common needs and aims are differently realized in different circumstances. This requires a great deal of knowledge that American students rarely received in previous eras: knowledge of non-Western cultures, of minorities within their own, and of differences of gender and sexuality.

Institutions of different sorts need to approach the challenge of world education differently, but all students should learn the fundamentals of the major world religions and the basics of world history. They should also master at least one foreign language. And they should learn how to inquire in greater depth into at least one unfamiliar world culture, while also learning about the experiences of minorities within their own.

\section{The Narrative Imagination}

But citizens cannot think well on the basis of factual knowledge alone. The third ability of the citizen, closely related to the first two, can be called the narrative imagination. This means the ability to think what it might be like to be in the shoes of a person different from oneself, to be an intelligent reader of that person's story, and to understand the emotions, wishes and desires that someone so placed might have. The narrative imagination is not uncritical: We always bring ourselves and our own judgments to the encounter with another, and when we identify with a character in a novel, or a distant person whose life story we imagine, we inevitably will not merely identify, but also judge that story in the light of our own goals and aspirations. But the first step of understanding the world from the point of view of the other is essential to any responsible act of judgment, since we do not know what we are judging until we see the meaning of an action as the person intends it, the meaning of a speech as it expresses something of 
importance in the context of that person's history and social world. The third ability our students should attain is the ability to decipher such meanings through the use of the imagination.

This ability is cultivated, above all, in courses in literature and the arts. Many standard and familiar works prepare students to understand the situation of people different from themselves. But there is also reason to incorporate works that confront students vividly with the experience of minority groups in their own society and of people in distant nations. The moral imagination can often become lazy, according sympathy to the near and the familiar, but refusing it to people who look different. Enlisting students' sympathy for distant lives is thus a way of training, so to speak, the muscles of the imagination.

\section{LAWYERS AS CITIZENS}

Now let us turn to the law. It is obvious enough that the main purpose of legal education is to produce lawyers. Legal education is a form of specialized professional training, and not a general preparation for citizenship and life. Moreover, in the United States, unlike most nations of the world, law students come to law school after completing an undergraduate liberal arts education. There are some good reasons to think that the values and goals of Cultivating Humanity are not germane to legal education: Students have had a general preparation for citizenship already, and what they are in law school to get is something very different.

On the other hand, lawyers are also citizens. Indeed, they are highly influential citizens. It has long been recognized that it is important for them to be ethical citizens, and courses in ethics are required by the American Bar Association itself. So there is evidence that law is understood as not simply a set of technical maneuvers, but as a way of being active and influential in public life that has a definite normative ethical dimension. Moreover, law students are active in public life in many different contexts: as clerks for judges (and, in a few cases, as judges themselves), as attorneys for multinational corporations, and as agents of government at many different levels. In these and many other ways, lawyers have the chance to set norms and directions for public life. Once again, then, a merely instrumental and technical preparation will not be sufficient to help them play this norm-setting role well.

Even when lawyers are not dealing with normative issues, they need to display some standard virtues of the Socratic citizen, such as the use of accurate and extensive information, respect for the argument of the opposing side, a capacity for reflection and deliberation, and a curiosity about the complexities of life. Again, a purely technical 
and instrumental education might not prepare them to cultivate those virtues, or to display them in their professional roles.

So it seems at least worth asking how each of the three capacities of the citizen, in my theory, might be relevant to legal education, and to what extent each is currently being instantiated in U.S. law school curricula.

\section{LEgAL Education: PuRsuing THE THREE CORE VALUES}

A. Socratic Self-Examination

This looks like the easy one, since, after all, the "Socratic Method" is still alive and relatively well in law school classrooms, and since logical ability is highly prized, both as an entrance qualification and as a criterion of assessment in course work. And yet, I have some worries. Few philosophy students, or even their teachers, have a lively understanding of exactly what Plato was talking about when he wrote the Gorgias, a work devoted largely to savage denunciation of rhetoricians and sophists. For the words "rhetorician" and "sophist" do not mean very much in today's world. Who are these people, who prefer to persuade the audience by whatever means, rather than to search for the truth by its own difficult and subtle means? Who are the ones who prefer to produce satisfaction rather than health? Well, one could do worse than to think of litigators. And because one purpose at least of legal education is to produce lawyers who win, legal education all too often blurs the distinction between sophistry and philosophy, clever argument and argument that tracks the truth. Even the hiring of young law faculty all too often focuses on the candidate's ability to give a dazzling display of rhetorical persuasiveness, rather than on the ability to inquire laboriously into what might actually be the case. ${ }^{15} \mathrm{Be}-$ ing a law professor and being a lawyer are very different roles, but often these roles get blurred, and too little thought is given to what qualities of mind are most appropriate for each. Even lawyers, however, need to be more reflective and deliberative than they are often encouraged to be.

The so-called Socratic Method is not very Socratic: Emphasis is placed on the ability to give quick answers, and to admit to being puzzled-a key Socratic virtue - will not get the student very far. Silence and introspective searching, often the hallmarks of good Socratic inquiry, are not much in evidence in the law school classroom. The class-

15 See Martha C. Nussbaum, Cooking for a Job: The Law School Hiring Process, 1 Green Bag 2d 253, 253-64 (1998) (criticizing the law school faculty hiring process for its inability to identify good scholars, as opposed to good rhetoricians). The title quote is from the Gorgias, the passage where Socrates compares rhetoric to cookery, which aims at pleasing the palate, as opposed to medicine, which aims at producing health. 
room culture usually values assertiveness, quickness, and confidencequalities we associate more with Socrates's interlocutors, such as Euthyphro and Critias, rather than with Socrates himself. In examinations, it is often more of the same: The ability cleverly to amass and organize a lot of material in a short time is the road to success, rather than the patient searching characteristic of Socratic inquiry.

Assuming one thinks that it might be good for young lawyers to understand the difference between sophistry and Socratic philosophy, and to be concerned with truth rather than just winning, what changes in the structure of legal education might promote these values? One change I would favor is more attention to paper-writing in basic courses, and a type of paper-writing in which the structure of the student's argument is carefully assessed and criticized, with serious comments by the instructor, as in a philosophy class. Examinations are a bad way to produce good arguments, and having to grade 150 examinations very rapidly is a very, very bad way to scrutinize the structure of an argument. Nor does the student get any useful feedback from this procedure.

Such a change would require other changes, bringing legal education closer to norms elsewhere in the academy. Classes would have to be much smaller, if the instructor is to do all the grading. An alternative would be the use of teaching assistants as graders, but then one would have to decide who those might be..$^{16}$ It is truly a difficult problem, whose adequate solution might require more faculty hiring, and thus a change in the financial structure of law schools. But one might compromise in the short run, assigning only one such paper, and devoting some classes to the public analysis of argumentative structure. One can also make good use of classroom debates, taking that occasion to point out some differences between trying to win and trying to get it right, and between macho point-scoring and respect for the argument of one's opponent. Students can be encouraged to look for examples of these differences in the cases put before them.

Having understood these differences, young lawyers will still rightly think that in certain contexts their proper role is to win, not to search for the truth, and to defeat, rather than to respect, their opponent. (Indeed, someone might say that what a good lawyer is, is a clever sophist, not a Socratic searcher.) A good defense attorney is not a private detective; a good litigator is not a fair arbiter of truth. Moreover, getting at the legal truth is not the same thing as getting at the moral truth, much though the general public often blurs that distinction: Precedent and statute play roles here that they do not play in

16 Using third-year students would introduce a problematic hierarchy among students; using graduate students from other disciplines who have law training would have its own problems. 
pure moral argument. Nonetheless, lawyers have many roles, and a law school has many roles. Among these are the pursuit of the academic values of precision and truth and the social values of truth and justice. We should get much clearer about what parts of a legal education promote each of these goals. Frank discussion even of these matters would be a lot more helpful than the confusion between sophistry and philosophy that sometimes reigns in a law school classroom, and to some extent in the legal academy more generally.

But Socrates's challenge was not just a request that people think more clearly. The "examined life" focuses on ethical excellence; its central goal is to figure out what virtue and justice are, critically examining the traditions of existing society. This part of Socrates's activity does not belong in all law courses, since lawyers need to learn the law as it is. But lawyers are also citizens, public figures, and agents of social change. They should learn to engage in normative ethical reasoning, by examining alternative accounts of decisionmaking, social justice, and other related topics. This normative dimension of legal education should not be confined to the required "Legal Ethics" course, typically a very narrow course concerned with professional conduct, but should permeate the curriculum, since normative questions and questions of justice are raised by all areas of law. This sometimes happens today, especially in areas such as constitutional law and environmental law, but it should happen more and more pervasively. All too often today, instead of addressing these questions seriously and rigorously, courses urge students to be cynical ("it's all self interest anyway") or relativistic ("who are you to judge?"). Students who choose law out of a passion for justice find in the curriculum too little that will channel that passion and render the thoughts involved in it more sophisticated and precise.

For this reason, law schools have increasingly formed partnerships with moral philosophers, and normative moral and political philosophy courses are playing an increasing role in many places. As someone whose role in the law school is to teach such courses, I have one major worry about them: One ends up all too often preaching to the converted, simply offering continuing education to students who majored in philosophy as undergraduates. One way we have tried to address this problem at the University of Chicago is through a course called "Decisionmaking," taught jointly by me and Professor Douglas Baird, an expert in the application of game theory to the law. Addressing both the analytical and the normative ethical aspects of good decisionmaking in public life, we acquaint students with expected utility theory, game theory, and the new behavioral law and economics. We have many students who basically think ethics is a "soft" subject. But we then get them reading Kant, Mill, and Aristotle, and odder authors 
still, such as Henry James and Mahasweta Devi. I am optimistic about the ability of courses such as this to expose a wide range of law students to good normative reasoning.

\section{B. World Citizenship}

Learning the law is obviously in the first instance a nation-based matter. The tradition of law that the U.S. shares with Great Britain (and India, Bangladesh, South Africa, Australia, Canada, and others) is not like the continental European tradition. The world contains numerous other types of legal systems as well. However, just as a student of U.S. history and politics gains a superior understanding of her subject through a comparative perspective that sets that history in a wider global context, so too a legal education can be illuminated in countless ways through the incorporation of a comparative perspective. (The comparative angle also helps Socratic questioning, since students come to see that our ways of doing things are not necessary and universal, and that reasonable people elsewhere have approached similar problems differently.) Courses in comparative law exist in most law schools, and ours even contains a new Center for Comparative Constitutionalism. ${ }^{17}$ Nonetheless, schools need to incorporate more comparative material into the presentation of issues of many different kinds. Often new casebooks in non-core areas do this better than the standard casebooks. Catharine MacKinnon's new Sex Equality casebook ${ }^{18}$ is a shining example, including material on sex equality issues from all over the world, and thus promoting a much richer understanding of where the world is with these problems, and how the U.S. stacks up against other nations.

But comparisons here and there do not go far to meet the full challenge of the contemporary world, with its increasingly global institutions, international agencies and agreements, and the huge influence of multinational corporations in every nation in which they work. More and more, our graduates go out to work in a multinational setting, for firms that either are multinational themselves, have multinationals as their clients, or both. They may, while remaining U.S. lawyers, live in Saigon or in London, representing clients who are major influences on the public policy of India and Bangladesh. As national sovereignty is increasingly compromised by the influence of the multinationals, one might even say that these corporations, and their lawyers, are ever more the makers of public policy for an interconnected world.

17 See http://ccc.uchicago.edu.

18 See generally Catharine MacKinnon, Sex Equality (Foundation 2001). 
A standard U.S. legal education of the old days is totally insufficient to equip young lawyers to play these new roles well, especially given most Americans' level of ignorance about affairs outside the United States. Normative Socratic reasoning about social justice is more necessary than ever before, since lawyers are increasingly called upon to reason outside a rigid institutional context. But it needs to be complemented by courses that acquaint students with the history of international law, international agencies and agreements, international human rights, and international business law (and preferably not the last without the others). They also need to have exposure to at least some of the most vexing problems of the developing world and the legal ramifications of these problems. Thus environmental law, education law, and poverty law, should all be increasingly taught in a global perspective. (We put Mahasweta Devi, a leading Bengali short-story writer who focuses on the lives of poor women, on the reading list for "Decisionmaking" in order to get students thinking about how the decisions a poor Bengali woman makes are constrained by her economic and sexual circumstances.)

Given the heavy weight of the standard "core" law courses, it is difficult to find room for this new international learning. But some adventurous law schools are trying hard. At the University of Michigan, under Dean Jeffrey Lehmann, all students are required to take a course in international law, and ambitious offerings in comparative and international law permeate the curriculum. At Georgetown, discussion is under way about a plan to develop some kind of comparative/international requirement for the first-year class, and international law is currently the most popular first-year elective. Columbia, long known for its strength in international law, human rights, and global governance, has developed some innovative alternative "tracks" for internationally concerned students, as well as an international law workshop. At The University of Chicago, in addition to an ongoing international law workshop, our law-philosophy workshop often focuses on international matters (Global Justice in 2000-01, War in 2002-03), and the Center for Comparative Constitutionalism holds symposia on a variety of international topics, focusing on the implementation of constitutional rights for disadvantaged groups. ${ }^{19}$

As an American Society of International Law report on "International Law and the Legal Curriculum" argues, ${ }^{20}$ a commitment to internationalizing the legal curriculum requires faculty development,

19 For the initial symposium of the Center, with contributions by Mark Tushnet, Richard Epstein, Cass Sunstein, and Iris Young, see 3 Chi J Intl L 429 (2002).

20 Charlotte Ku, Panel Report: International Law and the Legal Curriculum (ASIL 2002) (summarizing a panel discussion from the 96th Annual Meeting of the American Society of International Law). 
encouragement of appropriate student activities and journals, curricular development, and support for conferences and other related activities. Such commitments require both money and imagination. But the old-fashioned type of legal education does not prepare our students well for the world they will enter. As Dean Jeffrey Lehman, who has made a commitment to the international the hallmark of his deanship, expresses it:

Why do so many of us want to study foreign laws and international institutions? Why do we want to understand the norms that shape the behavior of nations? Why do we care about how another country regulates marriage, or pollution, or the press?

No doubt one reason is comparativist. We believe, rightly, that we will gain new insight into ourselves and our own legal system by better understanding how other societies and cultures have taken different paths to resolve similar social questions.

Yet I think an even more significant reason is fundamentally humanist. Even while we respect the legal importance of state borders, a core part of us subscribes to a "community" that includes all human beings .... Francis Allen described law as "a path to the world," and his words may be read literally as well as metaphorically. In their lives as lawyers, our graduates feel a sense of responsibility to a community that embraces the entire world. ${ }^{21}$

Seneca could not have put it better.

\section{The Narrative Imagination}

It might seem that the undergraduate curriculum is the right place for courses in literature and the arts that develop the capacity to think imaginatively about what it might be like to be in the situation of another. Law school is for drier, more technical types of learning. I believe that such a conclusion would be short-sighted. As noted above, the imagination of human predicaments is like a muscle: It atrophies unless it is continually used. And the imagination of human distress, fear, anger, and overwhelming grief is an important attribute in the law. Lawyers need it to understand and depict effectively the plight of their clients. Judges need it to sort out the claims in the cases before them. Lawyers advising corporations need it in order to develop a complete picture of the likely consequences of various policy choices for the lives of consumers, workers, and the public at large, including the public in distant countries where corporations do business. Factual knowledge is crucial, and in its absence the imagination can often

21 Jeffrey Lehman, Message From the Dean, 40 L Quadrangle Notes 2, 2 (Fall/Winter 1997). 
steer us wrong. But knowledge is inert without the ability to make situations real inside oneself, to understand their human meaning.

Because this ability is frequently so underdeveloped in quick, competitive, highly intelligent people, the narrative imagination needs particular thought in designing the content of legal education. As I have argued in Poetic Justice, ${ }^{22}$ there are many ways in which law courses can stimulate and further develop the imagination. ${ }^{23}$ For reasons of space, and because this is an issue on which I have already made proposals for the reform of legal education, I shall not repeat myself here.

It is, however, important to add to the account presented in Poetic Justice a warning regarding the newly popular type of course called "Law and Literature." I I used to teach such a course, and I now no longer do. The name "Law and Literature" denotes no clearly demarcated subject matter. My course did have a definite subject matter: It was the role played by compassion and empathy in the law, and I pursued that theme through literary ${ }^{25}$ and legal texts of many kinds. But, not surprisingly (despite the fact that I thought I had described the course clearly enough) students came to the course not expecting a sustained philosophical examination of the emotions, and expecting instead a lighter, more entertaining kind of course about literary representations of legal situations. Perhaps that sort of problem can be solved, but I think one cannot rely for the training I would like to promote, on elective courses of this nature, however well designed.

I now favor integrating the topic of imagination, and works that develop it, into courses of many different kinds, at many different levels. To give just one example: In "Decisionmaking," Douglas Baird and I assigned a wide range of narrative materials, including history, both narrative and documentary, narrative accounts of economic development projects, short stories (Mahasweta Devi's "Giribala" alongside Tillie Olson's "I Stand Here Ironing"), an extract from Henry James, and, in one memorable class, an actual living example of historical decisionmaking, as our colleague Professor Bernie Meltzer described, for

22 Martha C. Nussbaum, Poetic Justice: The Literary Imagination and Public Life xiii-xviii (Beacon 1996) (describing the value of literature in legal education).

23 A classic account, still extremely valuable, is James Boyd White, The Legal Imagination: Studies in the Nature of Legal Thought and Expression (Little, Brown 1973), the book that, more than any other, gave rise to the "law and literature" movement. See also James Boyd White, From Expectation to Experience: Essays on Law and Legal Education (Michigan 1999), especially the essays, Teaching Law and Literature, id at 73-88, and Meaning in the Humanities and the Law, id at 89-110.

24 In addition to White's work, probably the most influential book in this area, very different in approach from White's, is Richard A. Posner, Law and Literature (Harvard 2d ed 1998).

25 Nor, of course, are literary texts the only ones that develop the imagination of human predicaments. Historical and biographical materials are also of great importance, and sometimes more accessible to law students. 
the first time publicly, his own role in the attempt to rescue the Romanian Jewish children from extermination when he was head of the Foreign Finance Division in the State Department during World War II.

I believe that all these different texts had their role. The Henry James class had a particular delicacy; one very aggressive law student, having grappled well with the complexities of Maggie Verver's decision to meet her husband in their own home, called it a "magical" class. Meltzer's gentle account of anti-Semitism and obtuseness in high places had a power all its own. Sometimes the ability to imagine something is very much promoted by the surprise of having that historical event in the classroom itself. On the final exam, we asked students to analyze (in terms of different theoretical approaches they had studied) two narratives: one a historical account of the Bhopal disaster, and one a long extract from Samuel Richardson's Clarissa, in which Clarissa Harlowe explained to Anne Howe why she had run away with Lovelace. (If Professor Baird gravitated toward stories of war, I gravitated toward stories of women in difficulty; the combination was both provocative, and, I think, rewarding.) In short, the narrative imagination is not a thing on its own in a specialized course marked "literature." It is, or should be, a part of legal education in many different places and forms.

Lawyers are citizens. Indeed, they are highly influential citizens, both of their own nation and of the world. In this era of globalization, U.S. trained lawyers influence events in many countries around the world. Because law school selects for people who are quick, competitive, and aggressive, it is especially important to design an education that produces a more complex and deliberative type of human being than the human being who enters as a $1 \mathrm{~L}$. All too often, I fear that the opposite process occurs: Ambitious idealistic young people become narrower, more fixed on narrowly instrumental goals. The world of the law firm induces narrowness soon enough. Altering Seneca's phrase, we might say to ourselves: "Soon they will be out there working for firms. Meanwhile, while they are here, while they have time to deliberate and imagine, let us cultivate their humanity." 
